\title{
A Poem Not Written by Yannis Ritsos on the Day of My Birth
}

$$
7 / 25 / 67
$$

He arrived at the port too late, threw his unused ticket to the ground.

Out on the jetty, a naked boy stood pointing into the ship's wake, where gulls knifed green water for squid.

He walked straight past the café, didn't stop at the flower stall, touch blue beads on the mule's harness, or splash his face with fountain water.

On a list nailed to the butcher's red door, he found his name, misspelled. Do you see? another man asked, pointing at the names that were crossed out.

Wasps strafed the eaves of the customs house from their hangar of spit and newspaper, and yet, early that morning, smoke had freed itself from his ribbons of dusty tobacco.

Some meaning he found in three black plums, a thimble of cold ouzo sipped at noon, a blank canvas of stone in his pocket.

Confined by my white blanket, I see none of this, of course, since the lamps of my parents' house are off, the shades drawn tight against midsummer, the edicts of each shadow held at bay. 